O R I G I N A L

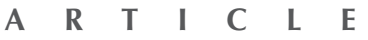

\section{CW Lai 黎千慧 \\ Frank WK Chan 陳允健}

\title{
Legislations combating counterfeit drugs in Hong
}

Kong

Key words Counterfeit drugs; Law enforcement;

Legislation

Hong Kong Med J 2013;19:286-93 DOI: 10.12809/hkmj133841

The Jockey Club School of Public Health and Primary Care, Faculty of Medicine, Prince of Wales Hospital, The Chinese University of Hong Kong, Shatin,

Hong Kong

CW Lai, BSc, PH (Hons)

FWK Chan, MB, ChB, FHKAM (Community Medicine

Correspondence to: Dr Frank WK Chan Email: cwkfrank@cuhk.edu.hk
Objective To understand legislation combating counterfeit drugs in Hong Kong.

Design This study consisted of two parts. In part I, counterfeit drugsrelated ordinances and court cases were reviewed. In part II, indepth interviews of the stakeholders were described.

Setting Hong Kong.

Participants All Hong Kong ordinances were screened manually to identify those combating counterfeit drugs. Court cases were searched for each of the identified cases. Then, the relevant judgement justifications were analysed to identify sentencing issues. Indepth interviews with the stakeholders were conducted to understand their perceptions about such legislation.

Results Trade Marks Ordinance, Patents Ordinance, Trade Descriptions Ordinance, and Pharmacy and Poisons Ordinance were current legislative items combating counterfeit drugs. Sentencing criteria depended on: intention to deceive, quantity of seized drugs, presence of expected therapeutic effect or toxic ingredients, previous criminal records, cooperativeness with Customs officers, honest confessions, pleas of guilty, types of drugs, and precautionary measures to prevent sale of counterfeit drugs. Stakeholders' perceptions were explored with respect to legislation regarding the scale and significance of the counterfeit drug problem, penalties and deterrents, drug-specific legislation and authority, and inspections and enforcement.

Conclusions To plug the loopholes, a specific law with heavy penalties should be adopted. This could be supplemented by non-legal measures like education of judges, lawyers, and the public; publishing the names of offending pharmacies; and emphasising the role of pharmacists to the public.

New knowledge added by this study

- Sanctioning factors considered by judges are intention to deceive, creation of confusion for average purchasers, quantity of counterfeits, ingredients and types of seized drugs, the offender's previous criminal record and attitude.

- Patients, pharmaceutical company representatives, lawyers, and Legislative Council members perceived the existing anti-counterfeit drug laws to be too lenient. Among these, the first three also suggested the need for a specific law to deal with counterfeit drugs.

\section{Implications for clinical practice or policy}

- Health care professionals should be more alert with regard to counterfeit drugs, refer suspected cases to the Customs and Excise Department or pharmaceutical company, and educate patients on proper drug purchasing practice.

- Counterfeit drug-specific legislation and heavy penalties appear necessary.

\section{Introduction}

Drugs can cure but also kill, especially if they are counterfeit. As defined by the World Health Organization (WHO), "a counterfeit drug is deliberately and fraudulently mislabelled with respect to identity and/or source. Counterfeiting can apply to both branded and generic products and may include the correct ingredients, the wrong ingredients, no active ingredients, or insufficient active ingredients, as well as fake packaging." 1,2

Drug counterfeiting is a global concern and a local threat. Globally, 10 to $15 \%$ of 
the drug supply is counterfeit. ${ }^{3}$ Among developing countries, $30 \%$ of total drug supply in Africa, $70 \%$ in Nigeria, and over $85 \%$ of certain drugs in China are counterfeit. ${ }^{3}$ China, the largest producer (responsible for $50 \%$ of counterfeit drugs in the world), transships fake drugs to Hong Kong., In Hong Kong, a study coconducted by a local university and The Alliance for Patients' Mutual Help Organizations has indicated a significant proportion of individuals as having bought fake drugs. ${ }^{5}$

Countries where high levels of counterfeit drug use prevail commonly have weak corresponding legislation. ${ }^{6}$ Reviewing current legislation can identify loopholes and offer implications for modifications. In the currently available literature, no studies have analysed local anti-counterfeit drug laws. This paper attempted to fill that gap.

\section{Methods}

The main purpose of this study was to understand the anti-counterfeit drug legislation in Hong Kong from a legal perspective, using a two-stage approach. Stage 1 was a systematic review of Hong Kong ordinances with the aim of identifying anti-counterfeit drug laws and their sanctioning. Stage 2 entailed qualitative indepth interviews with stakeholders to analyse their perceptions on the identified laws.

\section{Systematic review}

First, laws combating counterfeit drugs were identified by screening all Hong Kong ordinances in the 'Bilingual Laws Information System', an official legal database. ${ }^{7}$ Ordinances related to health, trade, trademarks, or patents were first identified. To further select counterfeit drug laws, opinions were sought from two experienced lawyers, one with expertise in trade, trademarks, and patent laws while the other had expertise in counterfeit drug laws. Regarding the final search result, both lawyers agreed that there was no omission of any relevant legislation. As some anti-counterfeit drug laws may not contain key words directly in the ordinance (eg Trade Descriptions Ordinance [TDO]), the screening process was conducted manually instead of electronically, in order to avoid omissions. Inclusion criterion I entailed coherence with WHO-specific guidelines for appropriate legislation (Appendix $I^{8}$ ), as judged from the detailed contents of the specific legislation.

Then, a systematic review was performed on court cases of each of the identified ordinances, in order to identify sanctioning factors. Court cases were located by searching all cases available in the database, Lexis (from 1909-2011) using the titles of the identified laws as the search key words (eg TDO). Inclusion criterion II entailed relatedness to counterfeit drugs and the presence of detailed

\section{香港打擊假藥的法例}

目的了解香港打擊假藥的現行法例。

設計 本研究包含兩部分。第一部分回顧假藥相關法例及其 案例報告。第二部分會與持份者深入訪談。

安排 香港。

參與者 首先從香港法例中篩選出打擊假藥的相關法例。然後 搜尋該法例的案例報告, 從中透過分析判詞以綜合量 刑因素。另外, 與持份者進行深入訪談以了解他們對 有關法例的意見。

結果 現時打擊假藥的法例包括商標條例、專利條例、商品 説明條例和藥劑業及毒藥條例。法官量刑時則會考慮 案件是否涉及刻意售賣假藥；售藥者有否採取適當措 施以防止售出假藥；假藥的數量、種類、是否達到預 期藥效或含有害物質; 售賣假藥者的犯罪紀錄；有否 配合海關人員的調查及是否認罪。對於相關法例，持 份者在多方面表達了他們的意見，包括假藥問題的規 模及嚴重性；罰則及阻哧作用；專門針對藥物的法例 及局方；以及巡查和執法情況。

結論 為堵塞漏洞, 必須採取專門針對假藥的法例及提升刑 䍗, 亦需配合一些非法例措施, 例如加強對法官、律 師和公眾的教育、公佈售賣假藥藥房的黑名單，及向 公眾強調藥劑師的角色。 reports stating sanctioning factors. It was determined by availability of detailed reports in the database and the presence of key words (counterfeit OR fake) AND (drug OR medicine OR therapeutics) OR patent infringement, in those reports (Appendix II). Detailed reports, if available, are spontaneously shown for each court case in the database.

\section{Qualitative stakeholder interviews}

To identify key opinion leaders (KOLs) in the field, counterfeit drug-related activities (eg 2009 AntiCounterfeit Drug Campaign) were first searched from Yahoo using (counterfeit OR fake) AND (drug OR medicine OR therapeutics) as key words. Seven active participants in these activities who were also leaders or representatives of relevant sectors (eg President of the largest patient group) were selected as KOLs. Their credentials afforded them substantial influence on and considerable knowledge about this issue. By snowball referral, 28 people who had working relationships with KOLs were approached to get relevant contact information and make appointments. Five KOLs agreed to be interviewed, including a senior representative of the largest pharmaceutical company worldwide who specialised in dealing with this issue, a senior Customs Officer responsible for counterfeit drug operations, a lawyer familiar with this issue, the President of one of the largest local patient support groups, and a Legislative 
Council (LegCo) member in the health-related Functional Constituency.

Each stakeholder was interviewed separately. An interview guide (Appendix III) was developed to facilitate the semi-structured in-depth interview. Questions were mainly open-ended. Ambiguous answers obtained were paraphrased and confirmed with the interviewee. Probes were used to elicit complete responses. The interviews lasted for 45 to 80 minutes. Interviewees were allowed to choose the venue so that they could feel comfortable during the process. Conversations were recorded and transcribed verbatim. Credibility was ensured by sending back the transcripts to the interviewee for a validity check. Thematic analysis was performed on the data using a code book so as to categorise it with similar key words into the same theme. To enhance reliability, coding and re-coding of the transcripts were performed.

\section{Ethical considerations}

Approval of this study was obtained from the Survey and Behavioural Research Ethics Committee of the Chinese University of Hong Kong. All participants were well informed about its objectives and implied consents were obtained. They were assured of their rights and freedom to withdraw at anytime.

To insure confidentiality, all interview data were only used in this research and not leaked to any third person. Real names were not included in the transcripts. Information that could allow others to guess the participant's identity was excluded. All data were saved in a password-protected file in a personal computer with a login password.

\section{Results}

\section{Ordinances and court cases review}

In all, 4 out of 1181 Hong Kong ordinances were identified to be relevant to anti-counterfeit drugs
(Table $1^{9}$ ). Among these, the TDO was used most frequently to combat counterfeit drugs. There were 505 court cases available in relation to these four ordinances, among which 17 were relevant under inclusion criterion II, for which there were eight detailed case reports (Appendix II). Sanctioning factors that the judge considered in these eight cases are listed below (Table 2):

- Intention to deceive, knowledge of the drugs being counterfeit;

- Enough precautionary measures taken to prevent sale of counterfeit drugs;

- Possibility of confusion to average purchasers;

- Quantity of seized drugs;

- Type of the drug, whether it was a lifestyle (recreational) or life-saving (to treat a serious condition) drug;

- Presence of expected therapeutic effect, toxic ingredients;

- Previous criminal record;

- Cooperativeness with Customs officers;

- Honest confession, plea of guilty.

\section{Stakeholders in-depth interviews}

\section{Scale and severity of the problem}

All stakeholders recognised the existence of the counterfeit drug problem. Some perceived the scale to be small, insignificant, and sporadic. Others suggested the possibility of hidden cases.

- LegCo member: "There must be counterfeit pills...only sporadic cases."

- Customs officer: "There are 3000-4000 pharmacies in Hong Kong...about 2\% have been found to sell counterfeit drugs...In this year, so far we only got 3-4 cases... The number of these cases is also very small, just 1-2 annually."

- Patient: "The statistics seem to be low so far, but we can't tell whether there is a large number of undetected cases."

TABLE I. Ordinances combating counterfeit drugs in Hong Kong and number of court cases identified for each ordinance ${ }^{9}$

\begin{tabular}{|c|c|c|c|c|}
\hline Type & Legislation & Description of the legislation & Maximum penalty & $\begin{array}{l}\text { No. of court } \\
\text { cases report }\end{array}$ \\
\hline Civil & $\begin{array}{l}\text { Trade Marks Ordinance } \\
\text { (Cap. 559) }\end{array}$ & $\begin{array}{l}\text { An Ordinance to make new provision in respect of the registration of } \\
\text { trademarks and to provide for connected matters }\end{array}$ & Not specified & 3 \\
\hline Civil & $\begin{array}{l}\text { Patents Ordinance } \\
\text { (Cap. 514) }\end{array}$ & $\begin{array}{l}\text { An Ordinance to make new provision in respect of patents and related } \\
\text { matters in substitution for the Registration of Patents Ordinance }\end{array}$ & Not specified & 0 \\
\hline Criminal & $\begin{array}{l}\text { Trade Descriptions } \\
\text { Ordinance (Cap. 362) }\end{array}$ & $\begin{array}{l}\text { To possess, sell or manufacture goods with false trade descriptions, } \\
\text { false, misleading or incomplete information, false marks and } \\
\text { misstatements is a criminal offence } \\
\text { To confer power to require information or instruction relating to goods } \\
\text { to be marked on or to be included in advertisements }\end{array}$ & $\begin{array}{l}\text { HK\$500 } 000 \text { fine; } \\
\text { 5-year imprisonment }\end{array}$ & 5 \\
\hline Criminal & $\begin{array}{l}\text { Pharmacy and Poisons } \\
\text { Ordinance (Cap. 138) }\end{array}$ & $\begin{array}{l}\text { To sell, offer for sale or distribute or possess for the purposes of sale, } \\
\text { distribution or other use of any pharmaceutical product or substance } \\
\text { is a criminal offence unless the product or substance is registered }\end{array}$ & $\begin{array}{l}\text { HK\$100 } 000 \text { fine; } \\
\text { 2-year imprisonment }\end{array}$ & 0 \\
\hline
\end{tabular}


TABLE 2. Court cases of the identified ordinances

\begin{tabular}{|c|c|c|c|c|}
\hline Cases & $\begin{array}{l}\text { Legisla- } \\
\text { tions }\end{array}$ & Case description & Penalty & Justification \\
\hline $\begin{array}{l}\text { Cheng Ping } \\
\text { Chung v } \\
\text { Edward Charles } \\
\text { Drown [1969] } \\
\text { HKCU } 30\end{array}$ & $\begin{array}{l}\text { Trade } \\
\text { Marks } \\
\text { Ordinance }\end{array}$ & $\begin{array}{l}\text { The defendant was charged for falsely } \\
\text { applying } 32400 \text { bottles to a certain } \\
\text { trademark; possessing those bottles with } \\
\text { the forged trademark; producing a mould } \\
\text { for forging the trademark; and selling } \\
\text { those bottles }\end{array}$ & No offence & $\begin{array}{l}\text { - No one is granted, under the Ordinance, an exclusive right to } \\
\text { the use of a given mark or device but only an exclusive right } \\
\text { to use a given mark or device in relation to certain goods or a } \\
\text { certain class of goods. Sufficient evidence is needed to show } \\
\text { an intention to deceive in relation to the particular goods with } \\
\text { its trademark registered }\end{array}$ \\
\hline $\begin{array}{l}\text { United States } \\
\text { Drug Store v } \\
\text { The Manager, } \\
\text { Sino-German } \\
\text { Dispensary } \\
\text { [1935] HKCU } 9\end{array}$ & $\begin{array}{l}\text { Trade } \\
\text { Marks } \\
\text { Ordinance }\end{array}$ & $\begin{array}{l}\text { The defendant was charged for } \\
\text { possessing and selling a packet of } \\
\text { 'Sinkilin', a patent medicine, which } \\
\text { has the trademark highly resembled } \\
\text { the trademark of another medicine, } \\
\text { 'Senkesin' }\end{array}$ & No offence & $\begin{array}{l}\text { - On the question of similarity, similarity of sound and } \\
\text { appearance are taken into consideration. In the English } \\
\text { version, the words were dissimilar in sound and appearance. } \\
\text { In the Chinese version, the characters, meanings, sound and } \\
\text { appearance are not similar. Possibility of confusion is not high } \\
\text { for average purchaser. Intention of the defendant to infringe } \\
\text { the trademark cannot be proven }\end{array}$ \\
\hline $\begin{array}{l}\text { In Re Galway } \\
\text { International } \\
\text { Ltd's Applica- } \\
\text { tion to Register } \\
\text { the Word Mark } \\
\text { "Vica" }\end{array}$ & $\begin{array}{l}\text { Trade } \\
\text { Marks } \\
\text { Ordinance }\end{array}$ & $\begin{array}{l}\text { The company applied to register the word } \\
\text { mark "VICA" }\end{array}$ & $\begin{array}{l}\text { Application } \\
\text { refused }\end{array}$ & $\begin{array}{l}\text { - Appearance, design and the word resembled another } \\
\text { registered word mark "VICKS" } \\
\text { - Possibility of confusion to the public exists }\end{array}$ \\
\hline $\begin{array}{l}\text { HKSAR v Lee } \\
\text { To Nei [2010] } \\
\text { HKCU } 2652\end{array}$ & $\begin{array}{l}\text { Trade } \\
\text { Descriptions } \\
\text { Ordinance }\end{array}$ & $\begin{array}{l}\text { The defendant was charged for } \\
\text { possessing and selling } 26 \text { bottles of } \\
\text { counterfeit herbal pills }\end{array}$ & $\begin{array}{l}\text { 6-Month } \\
\text { imprisonment }\end{array}$ & $\begin{array}{l}\text { - Pills were harmless for human consumption } \\
\text { - Defendant failed to exercise reasonable diligence but not } \\
\text { knowing pills were counterfeit }\end{array}$ \\
\hline $\begin{array}{l}\text { HKSAR v Chan } \\
\text { Yau Fat [2008] } 4 \\
\text { HKC } 320\end{array}$ & $\begin{array}{l}\text { Trade } \\
\text { Descriptions } \\
\text { Ordinance }\end{array}$ & $\begin{array}{l}\text { The defendant was charged for } \\
\text { possessing and selling } 68 \text { tablets of } \\
\text { Cialis and } 64 \text { tablets of Viagra with forged } \\
\text { trademarks applied }\end{array}$ & $\begin{array}{l}\text { 3-Month } \\
\text { imprisonment }\end{array}$ & $\begin{array}{l}\text { - Pills contained the active ingredient for the therapeutic effect } \\
\text { the purchasers intended } \\
\text { - No harmful ingredients } \\
\text { - First-time offender } \\
\text { - Honestly admitted the crime } \\
\text { - Pills were not for treating serious condition but for recreational } \\
\text { - use }\end{array}$ \\
\hline $\begin{array}{l}\text { HKSAR v } \\
\text { Chung Chun } \\
\text { Ming [2009] } \\
\text { HCMA 665 }\end{array}$ & $\begin{array}{l}\text { Trade } \\
\text { Descriptions } \\
\text { Ordinance }\end{array}$ & $\begin{array}{l}\text { The defendant was charged for } \\
\text { possessing and selling } 30 \text { tablets of } \\
\text { Viagra and } 20 \text { calcium injection shots } \\
\text { with forged trademarks applied }\end{array}$ & $\begin{array}{l}\text { 3-Month } \\
\text { imprisonment }\end{array}$ & $\begin{array}{l}\text { - Pleaded guilty } \\
\text { - Defendant knew that the drugs were counterfeit }\end{array}$ \\
\hline $\begin{array}{l}\text { The Queen v } \\
\text { Hui Man Sang } \\
\text { [1996] HCMA } \\
549\end{array}$ & $\begin{array}{l}\text { Trade } \\
\text { Descriptions } \\
\text { Ordinance }\end{array}$ & $\begin{array}{l}\text { The defendant was charged for } \\
\text { possessing for the purpose of } \\
\text { manufacturing } 26400 \text { bottles of } \\
\text { counterfeit pills with forged trademarks } \\
\text { applied }\end{array}$ & $\begin{array}{l}\text { 6-Month } \\
\text { imprisonment } \\
\text { suspended for } \\
2 \text { years }\end{array}$ & $\begin{array}{l}\text { - Pleaded guilty } \\
\text { - Ready cooperation with Customs officers } \\
\text { - No harmful ingredients } \\
\text { - No previous criminal record }\end{array}$ \\
\hline $\begin{array}{l}\text { Secretary for } \\
\text { Justice v Li Lap } \\
\text { Chun [2000] } 1 \\
\text { HKC } 227\end{array}$ & $\begin{array}{l}\text { Trade } \\
\text { Descriptions } \\
\text { Ordinance }\end{array}$ & $\begin{array}{l}\text { The respondent, a lorry driver, was } \\
\text { charged for possessing trade goods (Po } \\
\text { Chai Pills) with a forged trademark }\end{array}$ & $\begin{array}{l}\text { Guilty, penalty } \\
\text { not stated }\end{array}$ & $\begin{array}{l}\text { - The lorry driver did possess the pills even though he was } \\
\text { just transporting the pills. One hundred cartons of infringing } \\
\text { goods consisting of } 250000 \text { phials of pills with a forged } \\
\text { trademark were seized, which is a large commercial quantity }\end{array}$ \\
\hline
\end{tabular}

The Customs officer believed the quantity of them to the risk of buying counterfeit drugs.

pills circulating in the community was also small. Most of the counterfeit drugs had already been seized at borders; only a few were allowed to enter the community. Chances of exposure for consumers to counterfeit drugs would be low.

- "In 2008, 2009, there were 700,000 seized pills...most were seized at borders... Only $1 \%$ of cases are seized from the community... The possibility of buying counterfeit drugs is 2 out of 100 pharmacies."

Still, some stakeholders thought this issue should not be neglected. As counterfeit drugs were difficult to distinguish by the naked eye, consumers might have bought some without knowing it. Also, patients have to purchase self-financed items (SFI) from community pharmacies on their own, subjecting
- Lawyer: "one pill is already too many."

- Patient: "under the SFI policy...The risk of patients buying counterfeit drugs would be higher."

They thought counterfeit drugs would definitely induce health problems, either acute or chronic, overdose and even death. Their acute impact on health could include acute poisoning. Counterfeit drugs lacking therapeutic effect might allow progression of chronic diseases by delaying the expected benefits of treatment.

- Lawyer: "If the counterfeit pill contains harmful substance, you will be poisoned... the patient may die after taking the drug as the expected therapeutic effect in controlling heart attack is absent." 
- Customs officer: "drugs affect health."

- Pharmaceutical company: "if the fake drug can't control the patient's psychiatric condition, he may commit suicide or murder others."

- Patient: "Counterfeit drugs...fail to control their chronic diseases...lead to overdose... admitted into the hospital."

- LegCo member: "Taking counterfeit drugs could lead to death or entail zero therapeutic effect."

A financial impact could also be implicated as the medical burden is increased by increasing readmission rates and treatment times.

- Lawyer: "it prolongs treatment...They (patients) go back to the hospital to consult doctors when the drug is ineffective or leading to an adverse effect. It actually adds extra burdens onto the medical system".

\section{Penalties and deterrent effect}

All stakeholders except the Customs officer perceived the penalty of existing legislation to be too light to address the potential health impact.

- Pharmaceutical company: "The health impact is great but the penalty is relatively too light."

- Patient: "Imprisonment is seldom part of the sentence... Fine is the usual penalty and it is not heavy..."

As pointed out by the stakeholders, the court tends to give light penalties like fines owing to insufficient public health awareness by the judges.

- Lawyer: "Regarding the judiciary aspect, they didn't see the public health impact...Some judges may think that the drugs didn't kil anybody; were merely made of flour; thus, there was no need for heavy punishments.. Based on patent infringement...small quantity is identified, so the penalties are light..."

Stakeholders other than the Customs officer perceived the deterrent effect to be insignificant owing to the usual light penalties. Their rationale was that light penalties like fines were not commensurate with the substantial profit from selling counterfeit drugs. They believed the heavier penalty (eg imprisonment) would be a greater deterrent.

- Pharmaceutical company: "fining alone can't exert sufficient deterrent effect."

- Lawyer: "If the penalty becomes heavier, it can influence people's intention to commit the crime. If selling counterfeit drugs will only be fined for $\$ 500$, people won't ever hesitate. The profit...how would it be only $\$ 500$ ?"
- Patient: "The counterfeiters would think the cost is not that big...worth taking the risk... the TDO cannot deter selling, storing or distributing of counterfeit drugs."

- LegCo member: "You can't use fines to prevent the selling of counterfeit drugs. Imprisonment would be another story."

The Customs officer, however, did not think the light penalties were non-deterrent. He first proposed two punishment models-severity of punishment and certainty of punishment. The former emphasised heavy sanctions if caught, while the latter emphasised $100 \%$ probability of arrest. He perceived the certainty of punishment, which was also the current approach, to be a greater deterrent. To achieve that, the Customs office strived to ensure $100 \%$ probability of arrest, making pharmacy owners aware through high-profile arrests.

- "There are 2 aspects. The first is of course strict legislations with heavy penalty, like imprisonment..."severity of punishment". We are adopting "certainty of punishment". That means people are seized whenever they offend the laws... "certainty of punishment" can lead to a greater deterrent effect than failing to catch the offender for most of the time but giving heavy punishment in one successful seizing."

- "We send the pharmacies a message: we conduct inspection regularly and will catch you...with a high-profile."

\section{Inspections and enforcement}

Stakeholders admired the Customs' effort, efficiency, and input of resources and manpower in law enforcement but were concerned about existence of hidden cases. Customs officers, as law enforcers, described their work. They focus on patent infringements and prevent entry of counterfeit drugs at borders. In the community, they carry out monthly inspections and raids on pharmacies. Since 2007, they have conducted 44 inspections on western medicines. Since last year, they have conducted 12 inspections targeting Chinese medicines. They also work on intelligence and might send undercover customers to suspicious pharmacies. The officer did not perceive any particular difficulty in enforcement, which was accomplished through collaboration with pharmaceutical companies and other departments.

- "We work on patent infringements...stop the entry of counterfeit drugs into Hong Kong...operation takes place in every district monthly...We act upon intelligence... inspect suspicious pharmacies by sending undercover customers...For western medicines, we conducted 44 inspections 
since 2007. For Chinese medicines, we conducted 12 inspections since last year. We collaborate with pharmaceutical companies...Department of Health, the Police, overseas law enforcement units through analysing intelligence... enforcement is not difficult."

\section{Drug-specific legislation and authority}

Some stakeholders thought that existing legislation was not specific enough to tackle counterfeit drug issue. They believed that such legislation treated the issue as patent infringement and adopted an inappropriate business approach to penalise offenders. Thereby, the small quantity of drugs seized resulted in an insignificant penalty, and the underlying public health impact was not being addressed. A specific authority was needed to tackle the issue as the Customs office was distracted by other counterfeit products.

However, the LegCo member believed that owing to the relatively small population in Hong Kong, setting up a new authority to specifically handle counterfeit drugs appeared unnecessary and not cost-effective. The Customs officer believed that the problem was currently under control with features of escalation, indicating that current legislation was already adequate, without the need to set up a specific task force or agency.

- Pharmaceutical company: "The legislations in Hong Kong treat counterfeit drugs as a kind of patent infringement, without addressing the public health impact of drugs. There should be a drug-specific legislation instead."

- Lawyer: "There are specific legislations concerning food...for drugs, the impact would be much greater."

- Patient: "TDO is too broad that applies to all consumer products...drugs are different from general consumer products. Drugs are related to citizen's health...TDO is definitely not enough...the judges usually showed limited knowledge of counterfeit drugs...the current legislation takes a business approach to offer sanctions...A specific authority would help...Customs work against a lot of other counterfeit products."

- LegCo member: "There are only 7 million people in Hong Kong. Is that really necessary for the government to allocate resources to set up a new authority?...The costeffectiveness has to be proven."

- Customs officer: "The existing legislations are adequate...the problem is suppressed to a low level. No evidence is showing an escalation."

\section{Discussion}

\section{Scale and significance of problem}

Although the Customs official suggested that the problem is under control, the quantity of counterfeit drugs seized has actually increased over recent years (Table $\left.3^{10}\right)$. According to him, $2 \%$ of pharmacies were selling counterfeit drugs. Yet, considering presence of 3000 to 4000 community pharmacies in Hong Kong, that would indicate 60 to 80 offending pharmacies (averaging 3-4 per district). Thus, citizens are still subjected to a certain level of risk. Also, patients themselves have to purchase SFI in the community pharmacies. ${ }^{11}$ Such drugs include sildenafil (Viagra), certain antidepressants, pills for insomnia and losing weight. ${ }^{12}$ However, 60000 tablets of sildenafil and 25000 tablets of antidepressants, drugs for insomnia and weight loss were found to be counterfeit in 2008. ${ }^{12}$ Moreover, counterfeit drugs are hard to distinguish by appearance, ${ }^{13}$ and thus susceptible to buying counterfeit drugs. One pill is already too much to risk.

Counterfeit drugs containing harmful substances cause immediate health damage. Those made up of flour deprive patients of anticipated therapeutic effects, delay genuine treatment, allow progression of disease, mislead diagnoses, and may indirectly contribute to death or complications. Patients receiving incorrect doses may endure overdosing or insufficient therapeutic effect, drug resistance, or spread of infection., ${ }^{6,14}$ Counterfeit drugs are silent killers. Patients may remain unaware they are taking counterfeits. Government's medical financial burden increases due to increased hospital readmissions and treatments as well as adverse drug reactions.

\section{Anti-counterfeit drug laws}

According to a press release by the Food and Health Bureau (formerly Health, Welfare and Food Bureau), the highest penalty imposed under the TDO in 2004 was a fine of HK\$10 000. ${ }^{15}$ As perceived by the stakeholders, the penalties are too light. The deterrent effect is doubtful considering the lure of profit from the counterfeit drug business.

TABLE 3. Amount of counterfeit drugs seized over recent years $^{10}$

\begin{tabular}{lc}
\hline Year & Counterfeit drugs seized at retail level (HK\$) \\
\hline 2004 & 42000 \\
2005 & 140000 \\
2006 & 55000 \\
2007 & 220000 \\
2008 & 770000 \\
\hline
\end{tabular}


Severe punishment is also an effective deterrent and not mutually exclusive from certainty of punishment. ${ }^{16} \mathrm{Also}$, in counterfeit drug cases, their impact cannot be evaluated solely in monetary or quantitative terms, but also as a public health issue. The public health impact can be immense even from a small quantity of drugs. Some stakeholders believed that judges and prosecutors have insufficient public health awareness and might feel bound by the existing legislation. Current commercial legislation is inappropriate and inadequate and appears not to stress the importance of public health.

In the US, the Federal Food, Drug, and Cosmetic Act is a more specific piece of legislation than TDO with an anti-counterfeit drug rationale. ${ }^{9}$ The effectiveness of heavy penalties and specific legislation has already been well reflected by the small proportion of counterfeit drugs in the US market $(<1 \%) .{ }^{17}$ Despite such a small number of counterfeit drugs, the US passed the Counterfeit Drug Penalty Enhancement Act in 2011, which further increases penalties for counterfeit drugs trafficking to reflect public mood. The maximum penalty of 20 years' imprisonment and fines up to US\$4 million were even extended to first-time offenders. Repeat offenders could be fined up to US\$8 million. Institutions could be fined US\$10 million for a firsttime offence and US\$20 million for repeat offences. ${ }^{18}$ Zero tolerance towards counterfeit drugs set by the US is a good learning example for Hong Kong.

In Singapore, the Health Products Act was passed in 2007 as a specific form of prohibition against counterfeit health products. Maximum penalties were increased to a US\$80000 fine and 3 years' imprisonment. ${ }^{19}$ In 2007, only seven counterfeit drug cases were discovered..$^{20}$ In Taiwan, manufacture or importation of illegal drugs incurs a maximum of 10 years' imprisonment and a US\$312 000 fine. Starting from 2006, pharmacists involved in selling counterfeit drugs risked being suspended from practising for up to 3 years. Such stringent legislation successfully reduced counterfeit drugs available in 2008 in the market to be only $0.8 \% .^{20}$

Even in developing countries like Vietnam, the Pharmaceutical Law specifically targets counterfeit drug selling. Offenders can be imprisoned for 5 to 20 years, for life or even death, quite apart from having to pay heavy fines and being prohibited from drugrelated jobs for 1 to 5 years. ${ }^{21}$

In Nigeria, the Counterfeit and Fake Drugs Act specifically prohibits the production, importation, manufacture, sale, and distribution of counterfeit drugs. ${ }^{22}$

Obviously, Hong Kong is still not up to international standards with regard to having a specific and deterrent anti-counterfeit law. Clearly its laws should be amended, but more important such rules must be enforced.

Legal amendments can also be supplemented by non-legal means, including serialisation of medicinal products; pharmacovigilance; education of lawyers and judges dedicated to the public health impact of counterfeit drug issues. Such individuals can make presentations about the specific health implications of a certain counterfeit drugs in courts. They could also engage in public education on proper drug purchasing practices (barcode checking, buying drugs from trustworthy pharmacies), publication of a list of offending pharmacies in Consumer Council's CHOICE magazine, ${ }^{23}$ and emphasis on the pharmacists' role in monitoring patients' drug use.

\section{Strengths}

Being the first local study on legislation to combat counterfeit drugs, related Hong Kong ordinances were identified and several sentencing factors were revealed from an analysis of court cases. The views of KOLs from relevant stakeholders were also revealed. Items of official unpublished data were also obtained from the Customs office, eg the number and frequency of inspections conducted. Most importantly, attention was drawn to legal implications and the need for specific legislation and heavy penalties.

\section{Limitations}

As there was no counterfeit drug-specific legislation in Hong Kong, determination of counterfeit drugrelated laws was prone to a certain degree of subjectivity by the researchers and lawyers who were consulted. Not all court cases are reported in detail by judges and available in the database, nor are they reported by the Customs office or lawyers. Hence the total number of fine-sanctioning cases could not be determined and only eight were found. Thus, the extent to which the summarised sanctioning factors could be generalised might be limited and what weight to place on them could not be prioritised.

The small number of stakeholders interviewed was a shortcoming of this study. Such insufficiency was minimised however, by interviewing representatives of stakeholders with an important direct influence on relevant issues. A senior representative from one of the largest pharmaceutical companies in the world, a LegCo member, and a senior Customs officer specifically responsible for this issue, the President from the largest local patient organisation, as well as a lawyer experienced in dealing with counterfeit drug cases were interviewed as KOLs.

As drug counterfeiting is an underground activity, in-depth interview with the counterfeit drug dealers/producers and therefore important stakeholders was not possible. Information provided by the pharmaceutical company representative and 
the Customs officer (eg $2 \%$ of local pharmacies were counterfeit drug sellers) may have been biased owing to conflicts of interest, and should be analysed with caution. Also, as the government official was the only source that could provide such information, validation via other sources was not possible, though such official data might still serve to provide reference values. Besides, only serious and appeal cases might be reported in detail, explaining why only eight cases with detailed reports were available for analysis; nine other relevant cases available in the database had no detailed reports. Regarding the eight cases analysed, either acquittal or imprisonment was sanctioned. Justification for any fine-sanctioning could not be studied. Moreover, not every detail was included about these appeal cases, and other sentencing criteria may have been omitted.

Future in-depth research studying the results of implementing heavy penalties based on specific legislation in foreign countries with similarities to Hong Kong could provide further legislative insights.

\section{Appendices}

Additional material related to this article can be found on the HKMJ website. Please go to <http:// www.hkmj.org>, search for the appropriate article, and click on Appendix in PDF following the title.

\section{References}

1. Medicines: spurious/falsely-labelled/falsified/counterfeit (SFFC) medicines. Available from: http://www.who.int/ mediacentre/factsheets/fs275/en/index.html. Accessed 20 Feb 2011.

2. WHO. General information on counterfeit medicines. Available from: http://www.who.int/medicines/services/ counterfeit/overview/en/index.html. Accessed 1 Mar 2011.

3. Fenoff RS, Wilson JM. Africa's counterfeit pharmaceutical epidemic: the road ahead. The anti-counterfeiting and product protection program (A-CAPPP) paper series; 2009.

4. Corey CW. Counterfeit drugs pose dangers in 90 countries worldwide. 2010. Available from: http://allafrica.com/ stories/201010140968.html. Accessed 20 Feb 2011.

5. Alliance for Patients' Mutual Help Organization. Counterfeit drugs [in Chinese]. Available from: http://hkupop.hku.hk/ chinese/report/antidrug09/content/resources/release.pdf. Accessed 20 Feb 2011.

6. Morris J, Stevens P. Counterfeit medicines in less developed countries: problems and solutions. London: International Policy Network; 2006.

7. Department of Justice, Hong Kong. Bilingual Laws Information System. Available from: http://www.legislation. gov.hk/chi/what.htm. Accessed 14 Jun 2011.

8. WHO. Guidelines for development of measures to combat counterfeit drugs. Geneva: WHO; 1999.

9. Erowid. Drug Abuse Control Amendments of 1965. Available from: http://www.erowid.org/psychoactives/law/ law_fed_daca1.shtml. Accessed 20 Feb 2011.

10. LCQ 20: spurious pharmaceutical products [press release]. Legislative Council, Hong Kong. 2009 Oct 17. Available from: http://www.info.gov.hk/gia/general/200904/01/ P200904010168.htm. Accessed 12 Nov 2011.

11. Hospital Authority, Hong Kong. Drug formulary. Available from: http://www.ha.org.hk/hadf/en_welcome.html. Accessed 3 Oct 2011.

12. 60000 Fake impotence drug seized by Customs [in Chinese]. Hong Kong Economic Times 2008 Jul 17; Sect. A26.

13. Yankus W. Counterfeit drugs: coming to a pharmacy near you. New York. American Council on Science and Health. 2006. Available from: http://www.acsh.org/publications/ counterfeit-drugs-coming-to-a-pharmacy-near-you-2/. Accessed 19 Mar 2011.

14. Moszynski P. Cambodia cracks down on illegal drug vendors in bid to counter antimalarial resistance. BMJ 2010;340:c2622. cross ref

15. LCQ 8: combating counterfeit pharmaceutical products [press release]. Legislative Council, Hong Kong. 2005 Jun 29. Available from: http://www.info.gov.hk/gia/ general/200506/29/06290199. Accessed 12 Nov 2011.

16. Mendes SM. Certainty, severity, and their relative deterrent effects: questioning the implications of the role of risk in criminal deterrence policy. Policy Stud J 2004;32:5974. cross ref

17. Rudolf PM, Bernstein IB. Counterfeit drugs. N Engl J Med 2004;350:1384-6. cross ref

18. US Policymakers introduce Counterfeit Drug Penalty Enhancement Act. Available from: http://www.pharmamag.com/News/tabid/63/Entryld/425/US-PolicymakersIntroduce-Counterfeit-Drug-Penalty-Enhancement-Act. aspx. Accessed 12 Nov 2011.

19. Health Sciences Authority, Singapore. Singapore situation report. ASEAN-China Conference on Combating Counterfeit Medical Products; 2007.

20. World Health Professions Alliance. Background document on counterfeit medicines in Asia; 2011.

21. Combating counterfeit medicines in Vietnam. ASEAN-China Conference on Combating Counterfeit Medical Products. Jakarta; 2007.

22. Erhun WO, Babalola OO, Erhun MO. Drug regulation and control in Nigeria: the challenge of counterfeit drugs. Journal of Health \& Population in Developing Countries 2001;4:23-34.

23. Consumer Council, Hong Kong. Naming of shops involved in selling counterfeit drugs. Available from: http://www. consumer.org.hk/website/ws_en/consumer_alerts/recalls_ and_alerts/2011021501.html. Accessed 20 Mar 2011. 